\title{
Imaginação e criação na infância: ensaio psicológico
}

\author{
Jónata Ferreira de Moura*
}

VIGOTSKI, Lev. S. Imaginação e criação na infância: ensaio psicológico. Apresentação e comentários de Ana Luiza Smolka. Tradução de Zoia Prestes. São Paulo: Ática, 2009.

A obra, arquitetada em 1930, cujo autor dispensa apresentações, analisa a imaginação como uma formação especialmente humana e discute o trabalho pedagógico orientado para a experiência estética. O livro inicia-se com uma apresentação, seguida por oito capítulos, finalizando-se com uma breve biografia do autor e uma bibliografia selecionada de suas obras.

$\mathrm{Na}$ apresentação, Ana Luiza Smolka, aponta a obra "[...] como um instigante e polêmico conjunto de reflexões de Vigotski sobre as condições e as possibilidades da criação humana, da criação individual entretecida na construção histórica [...]" (p. 10), para ela, a obra mobiliza opiniões e compreensões, dentre elas, como a criança experiencia a trama e o drama.

Criação e imaginação - título do primeiro capítulo - é apresentado didaticamente por Vigotski que apresenta alguns aspectos da atividade humana e seus dois tipos básicos: 1) atividade reprodutiva e 2) atividade criadora. Para o autor, a imaginação é base de toda atividade criadora e se revela em todos os campos da vida cultural, tornando possível a criação artística, científica e técnica.

No segundo capítulo - Imaginação e realidade - o psicólogo russo defende a concepção de que a imaginação é uma função vital necessária e não um divertimento ocioso da mente humana. Esclarece, ainda, a relação entre fantasia e realidade como comportamento humano, assim, Vigotski demonstra as quatro formas principais dessa relação: a) toda imaginação é tomada de elementos da realidade e presentes na experiência anterior; b) o produto final da fantasia é um fenômeno complexo da realidade; c) a realidade é de caráter emocional; d) a construção da fantasia pode ser algo completamente novo.

No terceiro capítulo - O mecanismo da imaginação criativa - Vigotski se dedica a explicálo, referendando que, "[...] Nenhuma invenção ou descoberta científica pode emergir antes que aconteçam as condições materiais e psicológicas necessárias para seu surgimento. A criação é um processo de herança histórica em que cada forma que sucede é determinada pelas anteriores" (p. 42).
Em - A imaginação da criança e do adolescente - é destacada a importância da experiência para a atividade imaginadora do ser humano, explicando que, "[...] ao longo do processo de desenvolvimento da criança, desenvolve-se também a sua imaginação, que atinge a sua maturidade somente na idade adulta" (p. 45), assim desconstrói o mito de que a criança é mais criativa e imaginadora do que o adulto. No capítulo seguinte "os suplícios da criação" - ampliando a importância da experiência nessa atividade, Vigotski enfatiza o aspecto construtor, produtor e criador da imaginação.

No capítulo seis - A criação literária na idade escolar - o autor volta a dissertar sobre os aspectos constitutivos da imaginação criadora: memória, imaginação, emoção e a realização. Apresentando uma variedade significativa de informações que podem se constitui num interessante documento sobre as intenções de se conhecer e analisar a produção escrita das crianças. Fornece, ainda, elementos para visualizarmos o desenvolvimento e o domínio da forma escrita da linguagem pelas crianças, com isso, o autor mostra a importância dos diferentes gêneros textuais nesse processo.

No capítulo a seguir - A criação teatral na idade escolar - o foco está na dramatização para o desenvolvimento infantil. Vigotski nos alerta para os modos de compreender, explicar e valorizar essa atividade humana nas relações de ensinoaprendizagem, e evidencia o valor do processo na criação infantil, o ato de brincar e o faz de conta tornam-se mais significativos que o próprio resultado da (criação).

No oitavo e último capítulo - O desenhar na infância - o autor dialoga com psicólogos, artistas e educadores que se interessam pelo desenho das crianças e se preocupam em estudá-lo. Comenta as fases do desenho por eles descritas, concorda com as formulações apresentadas e destaca que, "Os quatro estágios no desenvolvimento do desenho infantil podem ser percebidos com mais nitidez ainda nos exemplos de representação das figuras humana e animal, que são os dois objetos que as

* Endereço eletrônico: jonatamoura@ @otmail.com 
crianças mais gostam de desenhar [...]" (p. 111).

Numa breve biografia que compõe o documento, Vigotski é apresentado pelo viés de suas clássicas obras em que discute o drama e a consciência dramática. Logo em seguida para finalizar, é apresentada uma bibliografia selecionada de textos do autor publicados em português no Brasil, uma seleção de textos dele com seus colegas da troika, outra de comentadores, em português, de seus livros e finaliza com referências em outros idiomas.

A obra, traduzido por Zoia Prestes, a qual esta resenha se refere, deixa claro o amplo potencial de conhecimento de Vigotski referente ao processo criativo infantil e sobre as pesquisas já realizadas sobre o tema, instiga seu leitor a buscar outros livros sobre essa temática.
Não se trata de um simples livro, com discussões e proposições, mas um documento que apresenta valiosas contribuições acerca da imaginação e da criação na infância, visto que mostra a experiência do drama vivido pela criança na apropriação das palavras dos outros, seja pela via literária ou pelo viés teatral.

Consideramos que o mesmo pode constituir-se de grande auxílio para profissionais da educação, haja vista que apresenta contribuições valorosas para aqueles que tenham interesse pelo tema, favorecendo o entendimento de como acontece o processo criador nas crianças e ainda a possibilidade do professor compreender seu papel no processo de criação infantil, uma vez que ressalta a importância do trabalho pedagógico para que as crianças participem da cultura.

\section{Sobre o autor:}

Jónata Ferreira de Moura: Mestrando do Programa de Pós-Graduação em Educação da Universidade São Francisco (USF) - Campus de Itatiba/SP. 